\title{
Determination of Fungi That May Cause Diseases to Athletes Which Spread in the Combat Sports Halls
}

Mohamed Abdel-Aziz Salama*, Waleed Mohamed Hedya**, Abeer Mohamed Abdel-Aziz Salama***

\begin{abstract}
:
This study aims at determining the fungi that cause disease to athletes, which spread in the combat sports halls. Approach: scanning approach from descriptive researches. Sample: Selected purposively form air and playing field of combat sports halls, (wrestling, fencing, boxing and selfdefense). Time and place: 17/03-20/05/2009, faculty of physical education for men Alexandria University, Egypt. Materials and method: Modified Sabouraud Dextrose agar medium was used. Opened plates method and the cotton swab technique were applied for fungal isolation. Results: Nineteen fungal isolates from air and playing field of combat sports halls. They cause diseases to athletes. Conclusion: (Acremonium kiliense, Alternaria alternate, Aspergillus flavus, Aspergillus fumigatus, Aspergillus niger, Aspergillus ochraceous, Cladosporium sphaerospermum, Curvularia hawaiiensis, Epicoccum nigrum, Fusarium chlamydosporum, Geotrichum candidum, Microsporum canis, Monilia sitophila, Nigrospora oryzae, Penicillium aurantiogriseum, Rhizopus arrhizus, Scopulariopsis brevicaulis, Trichophyton mentagrophytes, Trichophyton rubrum) Isolated from the combat sports halls and cause onychomycosis, keratitis, endophthalmitis, endocarditis, meningitis, peritonitis, osteomyelitis, phaeohyphomycosis, hypersensitivity, pneumonitis, otitis, sinusitis and invasive disease, aspergillosis, pulmonary disease, skin lesions, tinea capitis, tinea corporis, respiratory allergy, penicilliosis, otomycosis, necrotizing esophagitis, urinary tract infections, zygomycosis and dermatophytosis. Fungal isolates spreading in wrestling and self-defense halls more than in boxing and fencing halls.
\end{abstract}

\section{Introduction and Research Problem:}

A combat sport, also known as a Fighting sport, is a competitive contact sport where two combatants fight against each other to gain enough points or a condition to declare a single winner by means of using certain rules of direct engagement. These engagements rules and conditions are significantly different from the rules in simulated contact or combat meant for technical based challenges, practice, or demonstration in martial arts, typically with the aim of simulating parts of real hand to hand

\footnotetext{
* Professor and Head of Sports Administration and Recreation Department, Faculty of Physical Education for Boys, Alexandria University, Egypt.

** PhD. in Physical Education, Sports Physiology, Faculty of Physical Education for Boys, Alexandria University, Egypt.

*** Assistant Lecturer, Environmental Science Department, Faculty of Science, Port Said University, Egypt.
}

combat through kata and self-defense training. Boxing, kickboxing, amateur wrestling, judo, mixed martial arts; Muay Thai and Swordsmanship are examples of combat sports (Annesley, 2008).

Microbial infections are a fairly common disease entity in contact sports. Combat sports in particular provide a competitive environment in which viruses, bacteria and fungi thrive; that infections could hinder athlete's ability to perform their full potential, combat sports activities includes movements that may cause the skin to develop its heat and friction against athletic equipments. Compounded by perspiration, this friction commonly results in blisters that can be quite painful and diminishes the athlete's ability to compete, infections can be particularly upsetting to athletes because they are often unsightly and the athlete may not even 
have a pre-existing that diseases conditions to develop it (Basler, 2000).

The presence of microbial contamination in indoor environment has been confirmed by many studies around the world (Kanaani, 2009).

Since Feinberg's studies (1955), it has been well established that fungal spores play a major role in allergic diseases such as asthma, hay fever and hypersensitivity pneumonitis and that they may cause serious systemic infections in some areas. In most cases there is no exposure to true or opportunistically pathogenic fungi, but there are species that can act as allergens or cause other non-allergic symptoms [4].Moulds readily enter indoor environments by circulating through doorways, windows, ventilation systems, and air conditioning systems.

Spores in the air also deposit on people and animals, bags, and pets common carriers of mold into indoor environments. The most common sports halls moulds are Cladosporium, Penicillium, Aspergillus, and Alternaria (Bush, 1989 \& Hoppe, 1995).

The quality of air and the number of pathogens depend on the condition and cleanliness of the building, appropriate humidity and temperature and good ventilation, access to light, oxygen and water (Bartzokas, 1975; Apter et al., 1994; Verhoeff, 1994; Bachmann \& Myers, 1995).

The pathogenic process depends on the quality and the condition of the building as well as on the time of exposure to fungi spores present in the air (Bush, 1989 \& Hoppe, 1995).

One strategy would be to determine the initial source of the organisms that cause infections. In doing so, we would be better equipped to understand the transmission and construct methods to prevent the transmission of the fungi and molds. It is most likely that the mode of transmission of these infections is person to person. Combat sports require close body contact and often results in skin abrasions that provide a perfect opportunity for person-toperson transmission. However, fungi have been isolated from several inanimate objects as mats and floors (Kemna \& Elewski, 1996), may be responsible for prolonged transmission of fungal infections (Amow et al., 1991).
To raise the level of the athlete's performance and to protect them from diseases that can be deadly and painful, and then save time, effort, and money.

From all of the above the researchers urge to study the determination of fungi that cause diseases to athletes which spread in the combat sports halls.

\section{Aim of the Research:}

To determine the fungi that causes disease to athletes which spread in the combat sports halls.

\section{Aim Achieved:}

The aim is to be achieved through

- Isolation of fungi, which spread in the combat sports halls including air, and playing field.

- Identification of isolated fungi.

- Determination of isolated fungi that causes diseases to athletes.

\section{Hypotheses of Research:}

- Presence of Variety of fungi in the combat sports halls air.

- Presence of Variety of fungi in the combat sports halls playing field.

- Some of the fungal isolates cause diseases to athletes.

\section{Research Procedures:}

\section{Research Approach:}

The researcher used the scanning approach from descriptive researches as it suits the research nature.

\section{Research Sample:}

The research sample selected purposively form air and playing field of the following combat sports halls, freestyle and greco-roman wrestling, fencing, boxing and self-defense.

The sample was taken as following five areas from each hall, one from the center and four from the corners, except the fencing hall the sample was taken from five areas distributed 
along the fencing playing field, in equal distances, these procedures repeated three times with interval one week between the different isolations for both air and playing field, with total count 120 Petri-dishes.

\section{Research Domains:}

\section{Research Time:}

Isolation: 17/03-06/04/2001

Incubation and Purification: 17/03-27/04/2011

Identification: 28/04-20/05/2011

\section{Research Place:}

Sampling was performed at faculty of physical education for men Alexandria University from air and playing field of combat sports halls; freestyle and greco-roman wrestling, fencing and self-defense. Mycological researches conducted in faculty of science Alexandria University. Pure culture fungal slants were identified in the mycological center, Assiut University, Egypt.

\section{Materials:}

\section{Media used:}

The modified Sabouraud Dextrose agar medium was used, this medium is specific for routine isolation, growth, and cultivation of fungi, and it is composed of (g/l): Glucose, 20; Peptone, 10; Agar, 15. Chloramphenicol $500 \mathrm{mg}$ in $10 \mathrm{ml}$ of $95 \%$ ethanol (antibiotic) for inhibition of bacteria was added to molten medium and stir, autoclave (Mackenzie et al., 1986).

\section{Chemicals and solutions: Chemicals}

Glucose, peptone, $\mathrm{HCl}, \mathrm{NaOH}$, and agar. All are obtained from laboratory fine chemicals, El Naser Pharmaceutical chemicals Co.

Chloramphenicol, Sedico pharmaceuticals Co., 6th of October city - Giza - Egypt.

\section{Methods:}

\section{Media preparation:}

Dissolve agar in $500 \mathrm{ml}$ distilled water, dissolve glucose and peptone in $500 \mathrm{ml}$ distilled water and warm to $50^{\circ} \mathrm{C}$, combine. Chloramphenicol $500 \mathrm{mg}$ in $10 \mathrm{ml}$ of $95 \%$ ethanol was add to molten medium and stir, distribute in flasks, autoclave at $115^{\circ} \mathrm{C}$ for 15 minutes. The $\mathrm{pH}$ of unadjusted glucose peptone agar is about 5.6 (Mackenzie et al., 1986).

\section{Isolation techniques of microorganisms:}

Two techniques were used for isolation of fungi.

\section{Opened plate's method}

Air fungal isolation applied by opened plates method. Immediately after practice the windows were closed for at least $1 \mathrm{~h}$ prior to sampling, and then used 60 Petri-dishes, filled with modified Sabourauds Dextrose agar medium, opened in different combat sport halls for $1 \mathrm{~h}$. (Martino \& Luzi, 2008).

\section{Cotton swab technique}

The cotton swab technique was applied. In this technique, the fungal species were isolated immediately after practice before any playing field cleansing was done, to improve the chance of finding organisms. Using sterile moist cotton buds swabbed over the surface, cotton swabs were then used to distribute fungi on the media in Petri-dishes, and the isolation medium was modified Sabourauds Dextrose agar. This technique was applied on 60 plates (Booth, 1971; Chaisrisook et al., 1995; Mousa, 1999; Kohl et al., 2000). The playing field cleaning habits of the college and the hygiene of the individuals were not controlled or altered in any way.

\section{Isolated fungi incubation:}

The dishes of isolated fungi were incubated at $25{ }^{\circ} \mathrm{C}$, examined the agar plates daily for 14 days for growth. For purification and identification of fungi, the growing fungi were purified in pure cultures on slants of modified Sabourauds Dextrose agar medium (Kohl et al., 2000). 
Results:

Table (1)

The type and number of airborne fungal isolates identified in combat sports halls

\begin{tabular}{|c|c|c|c|c|c|}
\hline \multirow{3}{*}{ Fungi } & \multicolumn{4}{|c|}{ Combat sports halls air sample $n=60$ plate } & \multirow{3}{*}{ Total } \\
\hline & \multicolumn{4}{|c|}{ Number of airborne fungal isolates } & \\
\hline & Wrestling hall & Fencing hall & Boxing hall & $\begin{array}{l}\text { Self-defense } \\
\text { hall }\end{array}$ & \\
\hline Acremonium kiliense & 5 & & 1 & 6 & 12 \\
\hline Alternaria alternate & 219 & 60 & 97 & 164 & 540 \\
\hline Aspergillus flavus & 125 & 31 & 50 & 98 & 304 \\
\hline Aspergillus fumigatus & 8 & 2 & 5 & 4 & 19 \\
\hline Aspergillus niger & 310 & 78 & 131 & 233 & 752 \\
\hline Aspergillus ochraceous & 11 & 3 & 4 & 5 & 23 \\
\hline Cladosporium sphaerospermum & 616 & 154 & 299 & 415 & 1484 \\
\hline Curvularia hawaiiensis & 5 & & & 3 & 8 \\
\hline Epicoccum nigrum & 8 & 2 & 4 & 8 & 22 \\
\hline Fusarium chlamydosporum & 21 & 5 & 8 & 18 & 52 \\
\hline Geotrichum candidum & 8 & 2 & 3 & 4 & 17 \\
\hline Monilia sitophila & 8 & & 2 & 9 & 19 \\
\hline Nigrospora oryzaa & 11 & 3 & 1 & 7 & 22 \\
\hline Penicillium aurantiogriseum & 422 & 99 & 211 & 295 & 1027 \\
\hline Rhizopus arrhizus & 27 & 5 & 8 & 11 & 51 \\
\hline Scopulariopsis brevicaulis & 8 & & & 9 & 17 \\
\hline Total & 1812 & 444 & 824 & 1289 & 4369 \\
\hline
\end{tabular}

Table 1 Shows the results of sixteen airborne boxing and fencing halls, in descending order fungal isolates from wrestling, self-defense, with total count 4369. 
Table 2

The type, number and percentage of airborne fungal isolates identified in wrestling hall air

\begin{tabular}{|l|c|c|}
\hline \multicolumn{1}{|c|}{ Fungi } & $\begin{array}{c}\text { No. of } \\
\text { isolates }\end{array}$ & $\%$ \\
\hline $\begin{array}{l}\text { Cladosporium } \\
\text { sphaerospermum }\end{array}$ & 616 & 34.00 \\
\hline Penicillium aurantiogriseum & 422 & 23.29 \\
\hline Aspergillus niger & 310 & 17.11 \\
\hline Alternaria alternate & 219 & 12.09 \\
\hline Aspergillus flavus & 125 & 6.90 \\
\hline Rhizopus arrhizus & 27 & 1.49 \\
\hline Fusarium chlamydosporum & 21 & 1.16 \\
\hline Aspergillus ochraceous & 11 & 0.61 \\
\hline Nigrospora oryzaa & 11 & 0.61 \\
\hline Aspergillus fumigatus & 8 & 0.44 \\
\hline Epicoccum nigrum & 8 & 0.44 \\
\hline Geotrichum candidum & 5 & 0.44 \\
\hline Monilia sitophila & 5 & 0.44 \\
\hline Scopulariopsis brevicaulis & 8.44 \\
\hline Acremonium kiliense & 8 & 0.28 \\
\hline Curvularia hawaiiensis & 800 \\
\hline Totales & 8 & 0.28 \\
\hline
\end{tabular}

Table 3

The type, number and percentage of airborne fungal isolates identified in fencing hall air

\begin{tabular}{|l|c|c|}
\hline \multicolumn{1}{|c|}{ Fungi } & $\begin{array}{c}\text { No. of } \\
\text { isolates }\end{array}$ & $\%$ \\
\hline $\begin{array}{l}\text { Cladosporium } \\
\text { sphaerospermum }\end{array}$ & 154 & 34.66 \\
\hline Penicillium aurantiogriseum & 99 & 22.3 \\
\hline Aspergillus niger & 78 & 17.56 \\
\hline Alternaria alternate & 60 & 13.51 \\
\hline Aspergillus flavus & 31 & 6.97 \\
\hline Fusarium chlamydosporum & 5 & 1.13 \\
\hline Rhizopus arrhizus & 5 & 1.13 \\
\hline Aspergillus ochraceous & 3 & 0.67 \\
\hline Nigrospora oryzaa & 3 & 0.67 \\
\hline Aspergillus fumigatus & 2 & 0.45 \\
\hline Epicoccum nigrum & & 0.5 \\
\hline Geotrichum candidum & & 0.45 \\
\hline Acremonium kiliense & & 100 \\
\hline Curvularia hawaiiensis & & \\
\hline Monilia sitophila & & \\
\hline Scopulariopsis brevicaulis & & \\
\hline Tisolates & & \\
\hline
\end{tabular}


Table 4

The type, number and percentage of airborne fungal isolates identified in boxing hall air

\begin{tabular}{|c|c|c|}
\hline Fungi & No. of isolates & $\%$ \\
\hline Cladosporium sphaerospermum & 299 & 36.28 \\
\hline Penicillium aurantiogriseum & 211 & 25.61 \\
\hline Aspergillus niger & 131 & 15.90 \\
\hline Alternaria alternate & 97 & 11.77 \\
\hline Aspergillus flavus & 50 & 6.07 \\
\hline Fusarium chlamydosporum & 8 & 0.97 \\
\hline Rhizopus arrhizus & 8 & 0.97 \\
\hline Aspergillus fumigatus & 5 & 0.61 \\
\hline Aspergillus ochraceous & 4 & 0.49 \\
\hline Epicoccum nigrum & 4 & 0.49 \\
\hline Geotrichum candidum & 3 & 0.36 \\
\hline Monilia sitophila & 2 & 0.24 \\
\hline Acremonium kiliense & 1 & 0.12 \\
\hline Nigrospora oryzaa & 1 & 0.12 \\
\hline \multicolumn{3}{|l|}{ Curvularia hawaiiensis } \\
\hline \multicolumn{3}{|l|}{ Scopulariopsis brevicaulis } \\
\hline Total isolates & 824 & 100 \\
\hline
\end{tabular}

Tables $2-5$ Shows the results of airborne fungal isolates appearance percentage in the different combat sports halls, the most common culturable airborne fungi were Cladosporium, Penicillium and Aspergillus while Acremonium
Table 5

The type, number and percentage of airborne fungal isolates identified in Self-defense hall air

\begin{tabular}{|c|c|c|}
\hline Fungi & No. of isolates & $\%$ \\
\hline Cladosporium sphaerospermum & 415 & 32.20 \\
\hline Penicillium aurantiogriseum & 295 & 22.89 \\
\hline Aspergillus niger & 233 & 18.08 \\
\hline Alternaria alternate & 164 & 12.72 \\
\hline Aspergillus flavus & 98 & 7.60 \\
\hline Fusarium chlamydosporum & 18 & 1.40 \\
\hline Rhizopus arrhizus & 11 & 0.85 \\
\hline Monilia sitophila & 9 & 0.70 \\
\hline Scopulariopsis brevicaulis & 9 & 0.70 \\
\hline Epicoccum nigrum & 8 & 0.62 \\
\hline Nigrospora oryzaa & 7 & 0.54 \\
\hline Acremonium kiliense & 6 & 0.47 \\
\hline Aspergillus ochraceous & 5 & 0.39 \\
\hline Aspergillus fumigatus & 4 & 0.31 \\
\hline Geotrichum candidum & 4 & 0.31 \\
\hline Curvularia hawaiiensis & 3 & 0.23 \\
\hline Total isolates & 1289 & 100 \\
\hline
\end{tabular}

kiliense, Curvularia hawaiiensis, Monilia sitophila and Scopulariopsis brevicaulis didn't appeared in fencing hall air also Curvularia hawaiiensis and Scopulariopsis brevicaulis didn't appeared in boxing hall air. 
Table 6

The type and number of playing field fungal isolates identified in combat sports halls

\begin{tabular}{|c|c|c|c|c|c|}
\hline \multirow{3}{*}{ Fungi } & \multicolumn{4}{|c|}{ Combat sports halls air sample $n=60$ plate } & \multirow{3}{*}{ Total } \\
\hline & \multicolumn{4}{|c|}{ Number of fungal isolates } & \\
\hline & Wrestling mat & Fencing floor & Boxing floor ring & Self-defense mat & \\
\hline Alternaria alternate & 116 & 15 & 27 & 47 & 205 \\
\hline Aspergillus flavus & 96 & 11 & 14 & 29 & 150 \\
\hline Aspergillus niger & 130 & 7 & 26 & 46 & 209 \\
\hline Cladosporium sphaerospermum & 421 & 55 & 51 & 97 & 624 \\
\hline Curvularia hawaiiensis & 7 & 1 & 1 & 2 & 11 \\
\hline Epicoccum nigrum & 5 & 1 & & 2 & 8 \\
\hline Fusarium chlamydosporum & 12 & & 2 & 5 & 19 \\
\hline Microsporum canis & 35 & 5 & 4 & 8 & 52 \\
\hline Monilia sitophila & 3 & & & & 3 \\
\hline Nigrospora oryzaa & 9 & 1 & 1 & 2 & 13 \\
\hline Penicillium aurantiogriseum & 170 & 8 & 34 & 60 & 272 \\
\hline Rhizopus arrhizus & 19 & 3 & 2 & 6 & 30 \\
\hline Trichophyton mentagrophytes & 47 & 5 & 7 & 11 & 70 \\
\hline Trichophyton rubrum & 23 & 1 & 5 & 6 & 35 \\
\hline Total & 1093 & 113 & 174 & 321 & 1701 \\
\hline
\end{tabular}

Table 6. Shows the results of fourteen playing defense, boxing and fencing halls, in descending field fungal isolates from wrestling, self- order with total count 1701. 
Table 7

The type, number and percentage of playing field fungal isolates identified in wrestling hall

\begin{tabular}{|l|c|c|}
\hline \multicolumn{1}{|c|}{ Fungi } & No. of isolates & $\%$ \\
\hline Cladosporium sphaerospermum & 421 & 38.52 \\
\hline Penicillium aurantiogriseum & 170 & 15.55 \\
\hline Aspergillus niger & 130 & 11.89 \\
\hline Alternaria alternate & 116 & 10.61 \\
\hline Aspergillus flavus & 96 & 8.78 \\
\hline Trichophyton mentagrophytes & 47 & 4.30 \\
\hline Microsporum canis & 35 & 3.20 \\
\hline Trichophyton rubrum & 23 & 2.10 \\
\hline Rhizopus arrhizus & 19 & 1.74 \\
\hline Fusarium chlamydosporum & 12 & 1.10 \\
\hline Nigrospora oryzaa & 9 & 0.82 \\
\hline Curvularia hawaiiensis & 7 & 0.64 \\
\hline Epicoccum nigrum & 5 & 0.46 \\
\hline Monilia sitophila & 3 & 0.27 \\
\hline Total isolates & 1093 & 100 \\
\hline
\end{tabular}

Table 9

The type, number and percentage of playing field fungal isolates identified in boxing hall

\begin{tabular}{|l|c|c|}
\hline \multicolumn{1}{|c|}{ Fungi } & No. of isolates & $\%$ \\
\hline Cladosporium sphaerospermum & 51 & 29.31 \\
\hline Penicillium aurantiogriseum & 34 & 19.54 \\
\hline Alternaria alternate & 27 & 15.52 \\
\hline Aspergillus niger & 26 & 14.94 \\
\hline Aspergillus flavus & 14 & 8.05 \\
\hline Trichophyton mentagrophytes & 7 & 4.02 \\
\hline Trichophyton rubrum & 5 & 2.87 \\
\hline Microsporum canis & 4 & 2.30 \\
\hline Fusarium chlamydosporum & 2 & 1.15 \\
\hline Rhizopus arrhizus & 2 & 1.15 \\
\hline Curvularia hawaiiensis & 1 & 0.57 \\
\hline Nigrospora oryzaa & 1 & 0.57 \\
\hline Epicoccum nigrum & & \\
\hline Monilia sitophila & & \\
\hline Total isolates & & 100 \\
\hline
\end{tabular}

Table 8

The type, number and percentage of playing field fungal isolates identified in fencing hall

\begin{tabular}{|l|c|c|}
\hline \multicolumn{1}{|c|}{ Fungi } & No. of isolates & $\%$ \\
\hline Cladosporium sphaerospermum & 55 & 48.67 \\
\hline Alternaria alternate & 15 & 13.27 \\
\hline Aspergillus flavus & 11 & 9.73 \\
\hline Penicillium aurantiogriseum & 8 & 7.08 \\
\hline Aspergillus niger & 7 & 6.19 \\
\hline Microsporum canis & 5 & 4.42 \\
\hline Trichophyton mentagrophytes & 5 & 4.42 \\
\hline Rhizopus arrhizus & 3 & 2.65 \\
\hline Curvularia hawaiiensis & 1 & 0.88 \\
\hline Epicoccum nigrum & 1 & 0.88 \\
\hline Nigrospora oryzaa & 1 & 0.88 \\
\hline Trichophyton rubrum & 1 & 0.88 \\
\hline Fusarium chlamydosporum & & \\
\hline Monilia sitophila & & \\
\hline Total isolates & & 100 \\
\hline
\end{tabular}

Table 10

The type, number and percentage of playing field fungal isolates identified in self-defense hall

\begin{tabular}{|l|c|c|}
\hline \multicolumn{1}{|c|}{ Fungi } & No. of isolates & $\%$ \\
\hline Cladosporium sphaerospermum & 97 & 30.22 \\
\hline Penicillium aurantiogriseum & 60 & 18.69 \\
\hline Alternaria alternate & 47 & 14.64 \\
\hline Aspergillus niger & 46 & 14.33 \\
\hline Aspergillus flavus & 29 & 9.03 \\
\hline Trichophyton mentagrophytes & 11 & 3.43 \\
\hline Microsporum canis & 8 & 2.49 \\
\hline Rhizopus arrhizus & 6 & 1.87 \\
\hline Trichophyton rubrum & 6 & 1.87 \\
\hline Fusarium chlamydosporum & 5 & 1.56 \\
\hline Curvularia hawaiiensis & 2 & 0.62 \\
\hline Epicoccum nigrum & 2 & 0.62 \\
\hline Nigrospora oryzaa & 2 & 0.62 \\
\hline Monilia sitophila & 321 & 100 \\
\hline Total isolates & & \\
\hline
\end{tabular}


Table 11

Type, isolation source and pathogenicity of air and playing filed fungal isolates identified in combat sports halls




fencing, boxing, and self-defense halls, Fusarium chlamydosporum didn't appeared in fencing hall, Epicoccum nigrum didn't appeared in boxing hall finally Nigrospora oryzaa didn't appeared in self-defense hall.

Table 11 Showing that there is a presence of nineteen fungal isolates in air and on playing field, from wrestling, self-defense, boxing and fencing halls and the fungal human health effect except Epicoccum nigrum no documented infection in humans.

\section{Discussion:}

The combat sports halls that work as fungi reservoirs (Viegas et al., 2009), is also favoured by the organic matter accumulation, construction complexity, material selection, high temperatures and inadequate maintenance (Brandi et al., 2007), Some studies have shown high levels of humidity in sport environment, making it difficult to separate the high humidity effect from the fungi presence (Goyer et al., 2001). Other environmental variable such as velocity of air and flow of fresh air indoors are influenced by ventilation system, which are an aspect to consider when analyzing fungal contamination (Wu et al., 2005).

The playing fields can harbor organisms that responsible for diseases at the times and in the areas that we sampled. The playing field cleaning habits of the college and the hygiene of the individuals were not controlled or altered in any way. We studied the playing fields in the state in which the college kept them. We diagnosed infections in all sample cultures. So the playing fields were the source of the infections, and may also the exposure to the dermatophytes responsible for the infections when the infected players were practicing. Because the playing fields were not cleaned on a regular basis and also we increase our chance by sampling immediately after practice times.

The count and identification data showed variations in both fungal genera and species, this finding was reported by several workers (Neely et al., 2001; Montegut et al., 1991; Zyska, 1997). The identified genera suggest a mix contamination, originated from playing field and air (Macura, \& Gniadek, 2000), the most common culturable combat sports halls airborne fungi were Cladosporium, Penicillium and Aspergillus. Elevated concentrations of Aspergillus and Penicillium soil fungi were associated with the dirt floor and crawl-space type of basement (Miller et al., 2000).

Exposure to some fungi can induce diseases, while other species can cause primary infectious diseases. The inhalation of spores containing mycotoxins has been shown to cause many of the symptoms typically associated with the "sick building syndrome" as the spores of Aspergillus can cause hypersensitivity pneumonitis. (Bush, 1989; Su et al., 1992)

Athletes' fungal diseases are usually spread from person to person through direct skin contact or contact with shared items or surfaces that have touched a person's infection or by contaminated air. Fungi might spread more easily among athletes because during participation athletes have repeated skin-to-skin contact, get breaks in the skin such as cuts and abrasions that if left uncovered allow fungal spore to enter and cause infection, share items and surfaces that come into direct skin contact, and have difficulty staying clean (Anderson, \& Porter, 2007).

As a result of sports nature fungal isolates have been reported mostly in high physical contact sports halls such as wrestling and self-defense. However isolates have been reported less frequent among halls in other sports such as boxing and fencing with little physical contact during participation.

\section{Conclusion:}

From the aim of the research, isolated fungi, obtained results, and finally analysis of this data the researchers can deduct that this study showing the presence of nineteen different fungal species, (Acremonium kiliense, Alternaria alternate, Aspergillus flavus, Aspergillus fumigatus, Aspergillus niger, Aspergillus ochraceous, Cladosporium sphaerospermum, Curvularia hawaiiensis, Epicoccum nigrum, Fusarium chlamydosporum, Geotrichum candidum, Microsporum canis, Monilia sitophila, Nigrospora oryzae, Penicillium aurantiogriseum, Rhizopus arrhizus, Scopulariopsis brevicaulis, Trichophyton mentagrophytes, Trichophyton 
rubrum), which they are isolated from the combat sports halls air and playing field. The fungal isolates have been reported mostly in high physical contact sports (wrestling and selfdefense halls). However isolates have been reported less frequent among (boxing and fencing halls) with little physical contact during participation and they cause the following diseases: onychomycosis, keratitis, endophthalmitis, endocarditis, meningitis, peritonitis, osteomyelitis, phaeohyphomycosis, hypersensitivity, pneumonitis, otitis, sinusitis and invasive disease, aspergillosis, pulmonary disease, skin lesions, tinea capitis, tinea corporis, respiratory allergy, penicilliosis, otomycosis, necrotizing esophagitis, urinary tract infections, zygomycosis and dermatophytosis.

\section{Recommendations:}

\section{For the college management}

1. The application of standards in the construction of sports halls in terms of location, size, and quality of ventilation and easy cleaning.

2. Keep the indoor sport environment dry moisture and good Ventilation.

3. Select equipments and materials with easily cleaned surface.

4. Perform of routinely medical examination for the athletes and the professionals working in indoor sport environment.

5. Development of health education for the athletes of fungal diseases spread in the sports environment and the prevention methods.

\section{Recommendations for the athletes}

1. Avoiding the contact with infected person and do not use the others clothing.

2. Share shower after sport practice with antifungal soup to avoid fungal infection.

3. Keep skin dry as possible to reduce the fungal infection.

4. Must take off their cloth after the performed of the sport activity and washing it as soon as possible.

\section{Recommendations for the researchers}

Investigate more researches on other sports and other micro-organisms.

\section{References:}

1. Amow, P. M., Houchins, S. G. and Pugliese, G. 1991. An outbreak of tinea corporis in hospital personnel caused by a patient with Trichophyton tonsurans infection. Pediatric Infectious Disease Journal, 10:355- 359.

2. Anderson, B.J. and Porter, J. 2007. USA Wrestling MRSA and other Infection Facts. American Medical Association, 298.

Annesle, G. M. P. 2011. Combat sports amendment regulation . Combat Sports Act, P. 2.

3. Apter, A., Brache, A., Hodgson, M., Sidman, J. and Leng, W.Y. 1994. Epidemiology of the sick building syndrome. Journal of Allergy and Clinical Immunology, 94: 227-88.

4. Bachmann, M.O., Myers, J.E. 1995. Influences on sick building syndrome symptoms in tree buildings. Social Science \& Medicin, 40: 245-51.

5. Baddley, J. W., Moser, S. A., Sutton, D. A., and Pappas, P. G. 2000. Microascus cinereus (anamorph Scopulariopsis) brain abscess in a bone marrow transplant recipient. Journal of Clinic Microbiology, 38:395-397.

6. Balows, C. L. A., Sussman, M., Wilson, T.1998. microbiology and microbial infections, 9th edition. (4) Arnold, London, Sydney, Auckland, New York.

7. Bartzokas, C.A. 1975. Relationship between the meteorological conditions and the airborne fungal flora of the Athens metropolitan area. Mycopathologia, 8: 3-38.

8. Basler, R. S. W. 2000. Athletic skin problems need not affect performance. Article, the American Academy of Dermatology, PR Newswire, New York.

9. Booth, C. 1971. Methods in microbiology. Academic Press, London, 4.

10. Brandi, G., Sitis, M., Paparini, A., Gianfranceschi, G., Schiavano, G.F., Santi, M., Santoni, D., Magini, V. and Romano-Spica, V. 2007. Swimming pool and fungi: an 
environmental epidemiology survey in Italian indoor swimming facilities. International Journal of environmental health research, 17.

11. Bush, R. 1989. Aerobiology of pollen and fungal allergens. Journal of Allergy and Clinic Immunology, 84: 1120-4.

12. Chaisrisook, C., Suwannarit, P. and Aranyanak, C. 1995. Fungal deterioration of mural paintings in the royal temple. Proceedings of the 3rd International Conference on Biodeterioration of Cultural Property, Bangkok, Thailand. 116-137.

13. Chakrabarti, A., Das, A., Sharma, A., Panda, N., Das, S., Gupta, K. L., and Sakhuja, V. 2001. Ten years' experience in zygomycosis at a tertiary care centre in India. Journal of Infection, 42:261-266.

14. Deshpande, S. D. and Koppikar, G. V. 1999. A study of mycotic keratitis in Mumbai. Indian Journal of Pathology and Microbiology, 42:8187.

15. Farina, C., Vailati, F., Manisco, A., and Goglio, A. 1999. Fungaemia survey: a 10-year experience in Bergamo, Italy. Mycoses, 42:543548.

16. Frieden, I. J. 1999. Tinea capitis: asymptomatic carriage of infection. Pediatric Infectious Disease Journal, 18:186-188.

17. Goyer, N., Lavoie, J., Lazure, L., Marchand, G. 2001. Bioaerosols in the workplace: evaluation, control and prevention guide. Bibliothèque nationale du Québec, Institut de recherché en Sante et en Securite du Travail du Quebec.

18. Gupta, A. K., and Summerbell, R. C. 1999. Combined distal and lateral subungual and white superficial onychomycosis in the toenails. Journal of the American Academy of Dermatology, 41:938-44.

19. Hoog, G. S., Guarro, J., Gene, J. and Figueras, M. J. 2000. Atlas of clinical fungi, 2nd edition. (1) Centraalbureau voor Schimmelcultures, Utrecht, The Netherlands.

20. Hoppe, P.R. 1995. Indoor climate. Experientia, 49: 775-9.

21. Kanaani, H. F. R. 2009. Real time detection of airborne fungal spores and investigations into their dynamics in indoor air. Ph.D. thesis published, School of physical and chemical sciences, Queensland University of Technology. 1-256.

22. Kaufman, G., Horwitz, B.A., Duek, L., Ullman, Y., Berdicevsk,y I. 2007. Infection stages of the dermatophyte pathogen Trichophyton: microscopic characterization and proteolytic enzymes. Medical Mycology, 45:149-55.

23. Kemna, M.E. and Elewski, B.E. 1996. A US epidemiologic survey of superficial fungal diseases. Journal of the American Academy of Dermatology, 35:539-542.

24. Klich, M. A., and Pitt. J. I. 1988.A Laboratory Guide to Common Aspergillus Species and their Teleomorphs. Commonwealth Scientific and Industrial Research Organization, North Ryde, New South Wales, Australia.

25. 2Kohl, T. D., Martin, D. C., Nemeth, R. and Evans, D. L. 2000. Wrestling mats: are they a source of ringworm infections? Journal of Athletic Training, 35: 427-430.

26. Mackenzie, D.W.R., leoffler, W., Mantovani, A. and Fujikura T. 1986. Guidelines for the diagnosis, prevention and control of dermatophytosis in man and animals. World health organization, Geneva (WHO/CDS/VPH/86.67).

27. Macura, A.B. and Gniadek, A. 2000Fungi present in the indoor environment of a social welfare home. Preliminary study. Mikol Lek, 7: 13-7.

28. Martino, P.A. and Luzi, F., 2008.A method to evaluate the microbial air composition in rabbit farm. 19th World Rabbit Congress, Verona, Italy. 10-13.

29. Miller, J.D., Haisley, P.D., Reinhard, J.H. 2000.Air sampling results in relation to extent of fungal colonization of building materials in some water-damaged buildings. Indoor Air, 10: 146-51.

30. Montegut, D., Indictor, N. and Koestler, R. J. 1991. Fungi deterioration of cellulosic textile, environmental studies. Journal of Bioderioration and Biodegradation, 28 (2): 209-226.

31. Mousa, H. A. 1999. Fungal infection of burn wounds in patients with open and occlusive 
treatment methods. Eastern Mediterranean Health Journal, 5: 333-336.

32. Neely, A. N. and Orloff, M. M. 2001. Survival of some medically important fungi in hospital fabrics and plastics. Journal of Clinical Microbiology, 39: 3360-336.

33. Pritchard, R. C., and Muir, D. B. 1987. Black fungi: a survey of dematiaceous hyphomycetes from clinical specimens identified over a five-year period in a reference laboratory. Pathology, 19:281-284.

34. Schell, W. A. 2000. Unusual fungal pathogens in fungal rhinosinusitis. Otolaryngology Clinics of North America Journal, 33:367-373.

35. Segal, B. H., Walsh, T. J., Liu, J. M., Wilson, J. D. and Kwon-Chung, K. J. 1998. Invasive infection with Fusarium chlamydosporum in a patient with aplastic anemia. Journal of Clinical Microbiology, 36:1772-1776.

36. Singh A. B. and Kumar P. 2002.Common environmental allergens causing respiratory allergy in india. Indian Journal of Pediatrics, 69: 32, 45-250.

37. Steinbach, W. J. and Stevens, D. A. 2003. Review of newer antifungal and immunomodulatory strategies for invasive aspergillosis. Clinical Infectious Diseases, 37:157-187.

38. Su, H.J., Rotnitzky, A., Burge, H.A., Spengler, J.D. 1992. Examination of fungi in domestic interiors by using factor analysis, correlations and associations with home factors. Applied and Environmental Microbiology, 58: 181-6.

39. Talwar, P. and Sehgal,S. C. 1978. Mycotic infections of the eye in Chandigarh and neigbouring areas. Indian Journal of Medical Research, 67:929-933.
40. Verhoeff, A., Van Reenen-Hoekstra, E., Samson, R., Brunekreef, B., Wunen J. 1994. Fungal propagules in house dust. Allergy, 49: 533-9.

41. Viegas, C., Santos, C. S. and Rosado, L. 2009. Fungal contamination; the case of gymnasium with swimming pools professionals. Swimming pool \& spa international conference. 2,4 .

42. Walsh, T. J., Gonzalez, C., Roilides, E., Mueller, B. U., Ali, N., Lewis L. L., Whitcomb, T. O., Marshall, D. J. and Pizzo, P. A. 1995. Fungemia in children infected with the human immunodeficiency virus: new epidemiologic patterns, emerging pathogens, and improved outcome with antifungal therapy. Clinical Infectious Diseases, 20:900-906.

43. Wu,P. C., Li, Y. Y., Chiang, C. M., Huang, C. Y., Lee, C. C., Li, F. C. and Su, H. J. 2005. Changing microbial contaminations are associated with ventilation performance in Taiwan's air-conditioned office buildings. International Journal of Indoor Environment and Health, 15:19-26.

44. Zalar,Z., Frisvad, J.C., Gunde-Cimerman, N., Varga, J., and Samson, R.A. 2008. Four new species of Emericella from the Mediterranean region of Europe. Mycologia, 100: 779-795.

45. Zaugg, C., Monod, M., Weber, J., Harshman, K., Pradervand, S., Thomas, J., Bueno, M., Giddey, K., and Staib, P. 2009. Gene Expression Profiling in the Human Pathogenic Dermatophytes Trichophyton rubrum during Growth on Proteins, American Society for Microbiology, 8: 241-250.

46. Zyska, B.1997. Fungi isolated from library materials - a literature review. International Biodeterioration and Biodegradation, 4: 43-51. 
